\title{
Continuing professional development systems for medical physicists: A global survey and analysis
}

\section{W. Howell Round*}

\author{
School of Engineering, University of Waikato, Hillcrest Road, Hamilton 3240, New Zealand
}

Received 5 January 2012; received in revised form 23 February 2012; accepted 27 March 2012 Available online 21 April 2012

\section{KEYWORDS \\ Continuing professional development; Continuing professional education; Medical physicists}

\begin{abstract}
Continuing professional development (CPD) and continuing professional education (CPE) are seen as being necessary for medical physicists to ensure that they are up-to-date with current clinical practice. CPD is more than just continuing professional education, but can include research publication, working group contribution, thesis examination and many other activities. A systematic way of assessing and recording such activities that a medical physicist undertakes is used in a number of countries. This can be used for certification and licensing renewal purposes. Such systems are used in 27 countries, but they should be implemented in all countries where clinical medical physicists are employed.

A survey of the CPD systems that are currently operated around the world is presented. In general they are quite similar although there are a few countries that have CPD systems that differ significantly from the others in many respects. Generally they ensure that medical physicists are kept up-to-date, although there are some that clearly will fail to achieve that.

An analysis of what is required to construct a useful medical physics CPD system is made. Finally, the need for medical physicist professional organizations to cooperate and share in the production and distribution of CPD and CPE materials is emphasized.

(c) 2012 Associazione Italiana di Fisica Medica. Published by Elsevier Ltd. All rights reserved.
\end{abstract}

\section{Introduction}

Medical physicists need to undertake CPD to keep up-todate in their field. This is for the benefit of the individual, the institution that they work for, and in the case of those who are clinically involved, for the benefit of patients.
While continuing professional development (CPD) has been recognized for many years as being vital for a medical physicist's professional practice [1], there is very little literature on this matter (e.g. [2]). This paper discusses several issues regarding CPD that should be considered when constructing such a system and reports on and

* Tel.: +64 7 8384173; fax: +64 78384835 .

E-mail address: h.round@waikato.ac.nz.

1120-1797/\$ - see front matter @ 2012 Associazione Italiana di Fisica Medica. Published by Elsevier Ltd. All rights reserved. http://dx.doi.org/10.1016/j.ejmp.2012.03.006 
analyses an exhaustive study of the medical physicist CPD systems in use by medical physics professional organizations (MPPOs).

There are 27 countries that have CPD systems. They are common in Europe [3-5], North America [6-8] and more are being established in Asia/Oceania [9]. There appears to be only one system in Africa [10] and none in Central and South America. The systems tend to have many common elements and few substantial differences. All are points-based systems apart from that of the United Kingdom [11]. Points-based systems are those where medical physicists are awarded 'points' according to a defined scale for undertaking various CPD activities and must achieve a defined number of points over a specified period. Most of the systems are European-based and are quite similar as they, in general, conform to Policy Statement No. 10 of the European Federation of Organizations for Medical Physics [12,13].

\section{Defining continuing professional development}

Continuing professional development consists of a range of learning activities through which medical physicists, like other professionals, maintain and develop throughout their career to ensure that they retain their capacity to practice safely, effectively and legally within their evolving scope of practice. In many countries and professions [14-16] it is seen as being more than continuing professional education (CPE) or attending courses and conferences. It consists of a wide range of activities, both professional and educational, that contribute to the development and further education of medical physicists throughout their careers. It can be seen as human resource development as well as CPE, although the line between the two is blurred [17].

The sorts of activities that have been defined by MPPOs as being CPD are quite varied. They can generally be categorized into:

- Attending courses and conferences.

- Independent study such as reading journals and books.

- Research activities evidenced in the form of journal publications, conference presentations, writing books, supervising and examining research presented for higher degrees, refereeing submissions to journal and conferences.

Table 1 The CPD points systems used in different countries and the points allocated for attending courses, seminars, lectures and other learning activities. Units are $a=$ activity, $d=$ day, $e=$ exercise, $h=$ hour, $j=$ journal, $m=m o n t h, s=$ study, $\mathrm{t}=$ test, $\mathrm{w}=$ week.

\begin{tabular}{|c|c|c|c|c|c|c|c|c|c|c|}
\hline & $\begin{array}{l}\text { Australia and } \\
\text { New Zealand }\end{array}$ & Austria & Belgium & Canada & $\begin{array}{l}\text { Czech } \\
\text { Republic }\end{array}$ & Croatia & Denmark & Finland & France & Germany \\
\hline Points required & 250 & 250 & 180 & 50 & 40 & 100 & 250 & 250 & 250 & 250 \\
\hline $\begin{array}{l}\text { Period to obtain points } \\
\text { (years) }\end{array}$ & 5 & 5 & 3 & 5 & 10 & 4 & 5 & 5 & 5 & 5 \\
\hline $\begin{array}{l}\text { Average points required } \\
\text { per year }\end{array}$ & 50 & 50 & 60 & 10 & 4 & 25 & 50 & 50 & 50 & 50 \\
\hline \multicolumn{11}{|c|}{ Attending courses/seminars/lectures etc } \\
\hline $\begin{array}{l}\text { Courses, workshops, } \\
\text { tutorials, etc (per hour) }\end{array}$ & 1 & 1 & $\leq 1$ & & $1 / d$ & 1 & 1 & 1 & 1 & 1 or 2 \\
\hline $\begin{array}{l}\text { Longer courses, workshop } \\
\text { (per day or week or } \\
\text { workshop) }\end{array}$ & & & $2 / d$ & $1 / 1 / 2 d$ & $3 / d$ & $1-8$ & & & & 8 or $16 / d$ \\
\hline $\begin{array}{l}\text { Lectures (not examined) } \\
\text { (per hour) }\end{array}$ & 1 & 1 & 1 & & & & 1 & & 1 & 1 \\
\hline $\begin{array}{l}\text { Lectures (examined) } \\
\text { (per hour) }\end{array}$ & 2 & 2 & 1 & & & & 1.5 & & 1 & 1.5 \\
\hline $\begin{array}{l}\text { Conferences (per hour, } \\
1 / 2 \text { day, day or event) }\end{array}$ & $1 / \mathrm{h}$ & $8 / d$ & $8 / d$ & $1 / 1 / 2 d$ & $4 / d$ & & 1 or $0.5 / \mathrm{h}$ & & $1 / \mathrm{h}$ & $8 / d$ \\
\hline $\begin{array}{l}\text { Attending local educational } \\
\text { activities/scientific meeting }\end{array}$ & $1-2 / \mathrm{h}$ & $15 / y$ & $1 / \mathrm{h}$ & $1 / 1 / 2 d$ & 1 & & $1 / \mathrm{h}$ & $1 / \mathrm{h}$ & $1 / \mathrm{h}$ & $15 / y$ \\
\hline $\begin{array}{l}\text { Attend relevant courses } \\
\text { and lectures not on medical } \\
\text { physics }\end{array}$ & & & & $1 / 1 / 2 d$ & & & $\leq 10 / y$ & $0.5 / \mathrm{h}$ & & Varies \\
\hline \multicolumn{11}{|l|}{ Other Learning } \\
\hline $\begin{array}{l}\text { Formal on-the-job training } \\
\text { activities }\end{array}$ & & & & & & & & $0.5-1 / \mathrm{h}$ & $1 / \mathrm{h}$ & \\
\hline $\begin{array}{l}\text { Interactive learning } \\
\text { (internet, CD ROM } \\
\text { etc with evaluation) }\end{array}$ & & $1 / \mathrm{e}$ & & 1 & 2 & & & & & $1 / e$ \\
\hline $\begin{array}{l}\text { Self-directed learning } \\
\text { Specialized training visit } \\
\text { to another institution }\end{array}$ & $1 / \mathrm{h}$ & $\begin{array}{l}\leq 10 / y \\
4 / d\end{array}$ & $5 / y / j$ & & & & $0.5 / \mathrm{h}$ & $0.5 / \mathrm{h}$ & & $\begin{array}{l}10 / y \\
4 / d\end{array}$ \\
\hline $\begin{array}{l}\text { Study breaks abroad or } \\
\text { in other institutions }\end{array}$ & & & & & & & $10 / w$ & & & $4 / d$ \\
\hline
\end{tabular}


- Professional activities such as participation in national and international working groups.

CPD systems usually require medical physicists to participate in a range of activities that are relevant to the functions that they carry out in their employment. However, some CPD systems are restrictive in the activities that are accepted and may only consider attending approved courses and conferences as being CPD activities. They are better described as CPE systems.

\section{A survey of CPD systems for medical physicists}

Almost all of the CPD systems that are operating around the world are points-based, i.e. a certain number of points are awarded to individual medical physicists for the completion of defined CPD activities, and there is a requirement that a certain number of points must be achieved within a defined period of years. Also it should be noted that in some countries, a medical physicist may be prevented from continuing to practice if the required number of points is not achieved. In the USA, maintenance of certification by the American Board of Radiology has additional requirements; medical physicists must also pass an examination, complete 20 self-assessment modules and a "practice quality improvement" project. One system, that of the UK, is not points-based.

A survey of the medical physicists' points-based CPD systems in use around the world was carried out in the following manner. The various systems were downloaded from MPPO and other internet sites or were obtained directly from the MPPOs. The documents and web sites for the systems can generally be found in references [6-8,10,18-40], although it must be noted that some of the references only define the MPPO's web site and may not yet contain the details of the system. These sites are included in the reference list as the author is aware that some of the MPPOs intend to publish the details on their web sites in the near future. Documents and web sites that were not in English were translated with the Google language translator. A draft table (that later became Tables $1-5)$ that summarized more commonly-used activities of points-based systems was constructed. Many of the systems

\begin{tabular}{|c|c|c|c|c|c|c|c|c|c|c|c|c|c|c|}
\hline Greece & $\begin{array}{l}\text { Hong } \\
\text { Kong }\end{array}$ & Ireland & Italy & Japan & Korea & Netherlands & Norway & Romania & $\begin{array}{l}\text { South } \\
\text { Africa }\end{array}$ & Spain & Sweden & Switzerland & Taiwan & $\begin{array}{l}\text { USA } \\
(\mathrm{ABR}+ \\
\text { CAMPEP) }\end{array}$ \\
\hline 250 & 90 & 250 & 150 & 60 & 30 & 200 & 250 & 250 & 60 & 250 & 250 & 250 & 500 & 250 \\
\hline 5 & 3 & 5 & 3 & 5 & 3 & 5 & 5 & 5 & 2 & 5 & 5 & 5 & 5 & 10 \\
\hline 50 & 30 & 50 & 50 & 12 & 10 & 40 & 50 & 50 & 30 & 50 & 50 & 50 & 100 & 25 \\
\hline \multirow[t]{2}{*}{1 or 2} & 1 & 1 & $0.5-1.5$ & $1-10$ & & & $0.5-1$ & 1 & 1 & 1 & 1 or 2 & 1 & 2 or 5 & 1 \\
\hline & & & & & 2 & $2-6 / 1 / 2 d$ & & & & & & & & \\
\hline 1 & 1 & 1 & & & & & 1 & 1 & 1 & 1 & 1 & 1 & & 1 \\
\hline 2 & 1 & 1 & $0.5-1.5$ & & & & 2 & $1-2$ & 1 & 1.2 & 2 & 2 & & 1 \\
\hline 1 or $2 / h$ & $1 / \mathrm{h}$ & & $0.2 / \mathrm{h}$ & $1-3$ & & $5-6 / 1 / 2 d$ & $1 / \mathrm{h}$ & $1 / \mathrm{h}$ & $1 / \mathrm{h}$ & $1 / \mathrm{h}$ & $1 / \mathrm{h}$ & $1 / \mathrm{h}$ & 15 or 30 & $1 / \mathrm{h}$ \\
\hline \multirow[t]{2}{*}{$1 / \mathrm{h}$} & $1 / \mathrm{h}$ & $1 / \mathrm{h}$ & $1 / 2 \mathrm{~h}$ & 1 & $2-4$ & $2-5 / 1 / 2 d$ & $0.5 / \mathrm{h}$ & $1 / \mathrm{h}$ & $1 / \mathrm{h}$ & $1 / \mathrm{h}$ & & $1 / \mathrm{h}$ & 15 & $1 / \mathrm{h}$ \\
\hline & $1 / \mathrm{h}$ & $1 / \mathrm{h}$ & $0.5-1.5$ & & & & $0.5 / \mathrm{h}$ & & & $1 / \mathrm{h}$ & $1 / \mathrm{h}$ & & 2 & $1 / \mathrm{h}$ \\
\hline $1 / \mathrm{h}$ & & $1 / \mathrm{h}$ & $1 / \mathrm{h}$ & & & & $0.5 / \mathrm{h}$ & $\leq 10 / y$ & $1 / \mathrm{h}$ & $0.2 / a$ & & & & \\
\hline Varies & $1 / \mathrm{s}$ & $\leq 10 / y$ & $1 / \mathrm{h}$ & & & & $0.5 / \mathrm{h}$ & $1 / \mathrm{h}$ & $3 / e$ & & & & & $1 / a$ \\
\hline \multirow[t]{2}{*}{$\begin{array}{l}10 / y \\
\text { Varies }\end{array}$} & $1 / t$ & $\begin{array}{l}\leq 10 / y \\
\leq 5 / y\end{array}$ & $1-1.5 / \mathrm{h}$ & & & & $0.5 / \mathrm{h}$ & $\begin{array}{l}\leq 10 / y \\
\leq 5 / y\end{array}$ & & $\begin{array}{l}2 / j \\
5 / m\end{array}$ & $0.5 / \mathrm{h}$ & & & \\
\hline & & & & & & & $10 / w$ & & & & & & $25 / 3 m$ & \\
\hline
\end{tabular}


Table 2 Points awarded for teaching activities. Units are $\mathrm{c}=$ course, $\mathrm{d}=\mathrm{day}, \mathrm{h}=$ hour, $\mathrm{y}=\mathrm{year}$, $\mathrm{e}=\mathrm{exercise}, \mathrm{y}=\mathrm{year}$.

\begin{tabular}{|c|c|c|c|c|c|c|c|c|c|c|}
\hline & $\begin{array}{l}\text { Australia and } \\
\text { New Zealand }\end{array}$ & Austria & Belgium & Canada & $\begin{array}{l}\text { Czech } \\
\text { Republic }\end{array}$ & Croatia & Denmark & Finland & France & Germany \\
\hline Points required & 250 & 250 & 180 & 50 & 40 & 100 & 250 & 250 & 250 & 250 \\
\hline $\begin{array}{l}\text { Period to obtain points } \\
\text { (years) }\end{array}$ & 5 & 5 & 3 & 5 & 10 & 4 & 5 & 5 & 5 & 5 \\
\hline $\begin{array}{l}\text { Average points required } \\
\text { per year }\end{array}$ & 50 & 50 & 60 & 10 & 4 & 25 & 50 & 50 & 50 & 50 \\
\hline \multicolumn{11}{|l|}{ Teaching } \\
\hline $\begin{array}{l}\text { Presenting at local } \\
\text { educational activities/ } \\
\text { scientific meeting }\end{array}$ & 2 & & $5 / h$ & $1 / 3 \mathrm{~h}$ & & $1-4$ & $1 / \mathrm{h}$ & $1 / \mathrm{h}$ & 3 & 5 \\
\hline $\begin{array}{l}\text { Delivery of new lecture/ } \\
\text { seminar }\end{array}$ & 2 & & & $1 / 3 \mathrm{~h}$ & & 1 & 1 or 2 & $0.5-2 / h$ & $1 / \mathrm{h}$ & 5 \\
\hline $\begin{array}{l}\text { Delivery of repeated } \\
\text { lecture/seminar }\end{array}$ & 1 & & & $1 / 3 \mathrm{~h}$ & & $1 / 4 \mathrm{~h}$ & 0.5 or 1 & $0.5-2 / \mathrm{h}$ & $1 / \mathrm{h}$ & 5 \\
\hline $\begin{array}{l}\text { Teaching a course } \\
\text { (per semester) }\end{array}$ & & & & & & & & & & 5 \\
\hline $\begin{array}{l}\text { Teaching a course } \\
\text { (per student) }\end{array}$ & & & $1 / d$ & & & & & & $10 / y$ & \\
\hline $\begin{array}{l}\text { Producing instructional } \\
\text { materials (CD ROMs etc) }\end{array}$ & & & & & 25 & & & & & \\
\hline Short course presenter & & & & $1 / 3 \mathrm{~h}$ & & & & & & \\
\hline $\begin{array}{l}\text { Subject specific teaching } \\
\text { (per semester hour) }\end{array}$ & & 5 & & & & & & & & \\
\hline $\begin{array}{l}\text { Subject specific teaching } \\
\text { (per hour) }\end{array}$ & & & $1-2$ & & 2 & & & & & \\
\hline $\begin{array}{l}\text { Conference invited lecture } \\
\text { (per lecture) }\end{array}$ & 10 & & 15 & & & & 5 & & 15 & \\
\hline
\end{tabular}

are more detailed and have further sub-categorization of the activities that were not shown in the table. For example, there may be different numbers of points awarded for journal article authorship depending on whether one is first, second or third author. The draft table was then returned to MPPOs and other representatives familiar with the systems to confirm that the categorizations and points were correct. Several corrections were made and Table 1 describes the points systems as they were at the end of 2011.

Tables $1-5$ do not include the UK system as it is not points-based.

Table 3 Points awarded for research publication, editing and reviewing.

\begin{tabular}{|c|c|c|c|c|c|c|c|c|c|c|c|}
\hline & $\begin{array}{l}\text { Australia } \\
\text { and NZ }\end{array}$ & Austria & Belgium & Canada & $\begin{array}{l}\text { Czech } \\
\text { Republic }\end{array}$ & Croatia & Denmark & Finland & France & Germany & Greece \\
\hline Points required & 250 & 250 & 180 & 50 & 40 & 100 & 250 & 250 & 250 & 250 & 250 \\
\hline Period to obtain points (years) & 5 & 5 & 3 & 5 & 10 & 4 & 5 & 5 & 5 & 5 & 5 \\
\hline Average points required per year & 50 & 50 & 60 & 10 & 4 & 25 & 50 & 50 & 50 & 50 & 50 \\
\hline Publication of technical article & & 5 & & & & $1-8$ & 2 & & & 5 & \\
\hline Paper in non-reviewed journal, etc & $3-10$ & 5 & & 3 & 10 or 15 & $1-8$ & & 3 & $\leq 10$ & 5 & $2-10$ \\
\hline $\begin{array}{l}\text { Publication of paper in reviewed } \\
\text { journal, etc }\end{array}$ & 5 or 15 & 10 & $6-20$ & 5 & $13-30$ & $1-8$ & $2-20$ & 7 or 15 & $\leq 20$ & 10 & $2-20$ \\
\hline Conference paper & 5 & 5 & $3-10$ & 3 & $10-15$ & $1-8$ & $3-5$ & 2 or 3 & $3-10$ & 5 & $2-10$ \\
\hline Proceedings article & & 5 & & & & $1-8$ & & & & 5 & \\
\hline Conference poster & 5 & 5 & $2-6$ & 3 & $5-15$ & $1-8$ & $3-5$ & 2 or 3 & $2-6$ & 5 & $2-10$ \\
\hline Publication of a book & 30 & 5 & $15-50$ & 10 & 20 or 25 & $1-8$ & & & $\leq 50$ & 5 & $5-30$ \\
\hline Publication of a book chapter & 5 or 15 & 5 & $6-20$ & 5 & & $1-8$ & $2-20$ & $7-15$ & $\leq 20$ & 5 & $5-30$ \\
\hline $\begin{array}{l}\text { Peer-reviewed journal editor } \\
\text { (per year) }\end{array}$ & 10 & & & & & & & & & & \\
\hline Reviewing journal papers (per review) & & & & & & & 1 & 2 & & & \\
\hline $\begin{array}{l}\text { Peer-reviewed journal editorial board } \\
\text { member (per year) }\end{array}$ & 5 & & & & & & & & & & \\
\hline $\begin{array}{l}\text { Editor of book with multiple authors } \\
\text { (per book) }\end{array}$ & 20 & & & 10 & & & & & & & \\
\hline
\end{tabular}




\begin{tabular}{|c|c|c|c|c|c|c|c|c|c|c|c|c|c|c|}
\hline Greece & $\begin{array}{l}\text { Hong } \\
\text { Kong }\end{array}$ & Ireland & Italy & Japan & Korea & Netherlands & Norway & Romania & $\begin{array}{l}\text { South } \\
\text { Africa }\end{array}$ & Spain & Sweden & Switzerland & Taiwan & $\begin{array}{l}\text { USA } \\
(\text { ABR + } \\
\text { CAMPEP) }\end{array}$ \\
\hline 250 & 90 & 250 & 150 & 60 & 30 & 200 & 250 & 250 & 60 & 250 & 250 & 250 & 500 & 250 \\
\hline 5 & 3 & 5 & 3 & 5 & 3 & 5 & 5 & 5 & 2 & 5 & 5 & 5 & 5 & 10 \\
\hline 50 & 30 & 50 & 50 & 12 & 10 & 40 & 50 & 50 & 30 & 50 & 50 & 50 & 100 & 25 \\
\hline $2-10$ & $3 / \mathrm{h}$ & $2 / \mathrm{h}$ & & 1 & & 2 & 3 & $\leq 10$ & & 2 & 1 or $3 / h$ & $3 / \mathrm{h}$ & $5 / h$ & \\
\hline 10 & $3 / \mathrm{h}$ & 10 & $1 / 1 / 2 h$ & $1-5$ & & & $1-6 / h$ & $\leq 10$ & 3 & $2 / \mathrm{h}$ & 3 or $6 / h$ & $3 / \mathrm{h}$ & $5-30 / h$ & \\
\hline \multirow[t]{4}{*}{2} & $3 / \mathrm{h}$ & 3 & $1 / 1 / 2 h$ & & & & $0.3-2 / h$ & $\leq 3$ & 3 & $1 / \mathrm{h}$ & 1 or $2 / h$ & 10 & $5-10 / h$ & \\
\hline & $3 / \mathrm{h}$ & & & & & 5 & & $5 / c$ & 5 or 10 & & & & $5-10$ & \\
\hline & 1 & & 2 & & & & & & & & & & & \\
\hline & 5 & & & 3 or 5 & $2 / \mathrm{h}$ & 5 & & & & 10 & & & & \\
\hline
\end{tabular}

\section{Overview of the points systems (Table 1)}

Most commonly the points accumulation period is five years, although in South Africa it is as short as two years and in the Czech Republic and the USA it is as long as ten years. This period may be defined to start and stop at set dates, or may be a continuous system where the points obtained must be over the previous period of years.
There is no compelling reason why the points should preferably be obtained on a continuous basis or with set dates.

In most countries medical physicists are expected to achieve 40-60 points per year, although this can be considerably lower. For example, in the Czech Republic only 4 points per year are required while 10 are required in Korea and Canada and 12 in Japan.

\begin{tabular}{|c|c|c|c|c|c|c|c|c|c|c|c|c|c|}
\hline Hong Kong & Ireland & Italy & Japan & Korea & Netherlands & Norway & Romania & South Africa & Spain & Sweden & Switzerland & Taiwan & $\begin{array}{l}\text { USA (ABR } \\
+ \text { CAMPEP) }\end{array}$ \\
\hline 90 & 250 & 150 & 60 & 30 & 200 & 250 & 250 & 60 & 250 & 250 & 250 & 500 & 250 \\
\hline 3 & 5 & 3 & 5 & 3 & 5 & 5 & 5 & 2 & 5 & 5 & 5 & 5 & 10 \\
\hline 30 & 50 & 50 & 12 & 10 & $\begin{array}{l}40 \\
3-15\end{array}$ & 50 & 50 & 30 & $\begin{array}{l}50 \\
5\end{array}$ & 50 & 50 & 100 & 25 \\
\hline & $2-20$ & 0.5 or 1 & $2-4$ & & 3 or 10 & 2 & & & 4 or 7 & 2 & & & \\
\hline $1-10$ & $2-20$ & 1 or 3 & $3-10$ & $2-4$ & 5 or 15 & $2-20$ & $\leq 20$ & 5 or 15 & 8 or 15 & 20 & $\leq 32$ & 30 & \\
\hline $1-5$ & $2-10$ & 0.5 or 1 & $1-3$ & & 5 & 3 or 5 & $\leq 10$ & 15 & 4 or 6 & 2 or 3 & $\leq 12$ & $\leq 20$ & \\
\hline $1-5$ & & & & & & 2 or 10 & & 5 & & 5 or 10 & & & \\
\hline $1-5$ & $2-10$ & 0.5 or 1 & & & 5 & 3 or 5 & $\leq 10$ & 5 or 15 & 4 or 6 & 2 or 3 & $\leq 12$ & $\leq 20$ & \\
\hline 10 & $5-30$ & & 3 or 7 & & & & & 15 & 8 or 15 & & & & \\
\hline 5 & $\begin{array}{l}5-30 \\
15\end{array}$ & 1 or 2 & & & 5 & $2-20$ & $\leq 50$ & 15 & 8 or 10 & & & & \\
\hline 2 & 5 & & & & $\begin{array}{l}5 \\
5\end{array}$ & 2 & & 3 & & & & & 1 or 2 \\
\hline 10 & 30 & & & & 5 & & & & 15 & & & & \\
\hline
\end{tabular}


Table 4 Points awarded for implementing new technologies and procedures and for professional service. Units are $\mathrm{c}=$ committee, $\mathrm{d}=$ day, $\mathrm{r}=$ report, $\mathrm{y}=$ year.

\begin{tabular}{|c|c|c|c|c|c|c|c|c|c|c|c|}
\hline & $\begin{array}{l}\text { Australia and } \\
\text { New Zealand }\end{array}$ & Austria & Belgium & Canada & Czech Republic & Croatia & Denmark & Finland & France & Germany & Greece \\
\hline Points required & 250 & 250 & 180 & 50 & 40 & 100 & 250 & 250 & 250 & 250 & 250 \\
\hline $\begin{array}{l}\text { Period to obtain points } \\
\text { (years) }\end{array}$ & 5 & 5 & 3 & 5 & 10 & 4 & 5 & 5 & 5 & 5 & 5 \\
\hline $\begin{array}{l}\text { Average points required } \\
\text { per year }\end{array}$ & 50 & 50 & 60 & 10 & 4 & 25 & 50 & 50 & 50 & 50 & 50 \\
\hline $\begin{array}{l}\text { Implementing new } \\
\text { technologies/procedures } \\
\text { (per report) }\end{array}$ & $3-10$ & & 5 & 5 & 20 & $<8$ & $\leq 10 / y$ & 5 & 5 or 10 & & 5 \\
\hline $\begin{array}{l}\text { Membership in task groups, } \\
\text { committees (per group } \\
\text { per year) }\end{array}$ & & 3 & 5 & 2 & & & & & 5 & 5 & 5 \\
\hline $\begin{array}{l}\text { Attending task groups, } \\
\text { committees (per meeting } \\
\text { or day) }\end{array}$ & & & 2 & & & & 1 or 2 & 1 or 2 & 1 & 3 & \\
\hline $\begin{array}{l}\text { Chairing task groups, } \\
\text { committees (per report) }\end{array}$ & & & 5 & & & & & & 5 & & \\
\hline $\begin{array}{l}\text { Service to professional } \\
\text { societies }\end{array}$ & 7 to 15 & & & 2 or 5 & & & & & & & \\
\hline $\begin{array}{l}\text { Conference organizing } \\
\text { and session chairing }\end{array}$ & $1-15$ & & & & & $1-4$ & & & & & \\
\hline
\end{tabular}

In the USA, medical physicists are required to do more than just achieve a certain number of CPD points within a ten-year period to maintain their American Board of Radiology certification. They must also complete 20 self-assessment modules, an examination and undertake a Practice Quality Improvement program [7].

There are often limits to how many points an individual may obtain in a year for a particular activity or range of activities. This is to ensure that participants partake in a wide variety of activities rather than gaining all of their points in a narrow range of activities, or even a single activity. These are generally not shown in Tables 1-5 apart from a few instances where the number of points that can be acquired in a single instance is not specified but a maximum number of points that can be accumulated in a year is specified.

For many activities there is often a requirement that the activity (such as a conference or seminar) must be

Table 5 Points awarded for supervision, examination and obtaining higher qualifications. Units are $\mathrm{c}=\mathrm{credit}, \mathrm{m}=\mathrm{month}$, $\mathrm{t}=$ thesis, $\mathrm{y}=$ year.

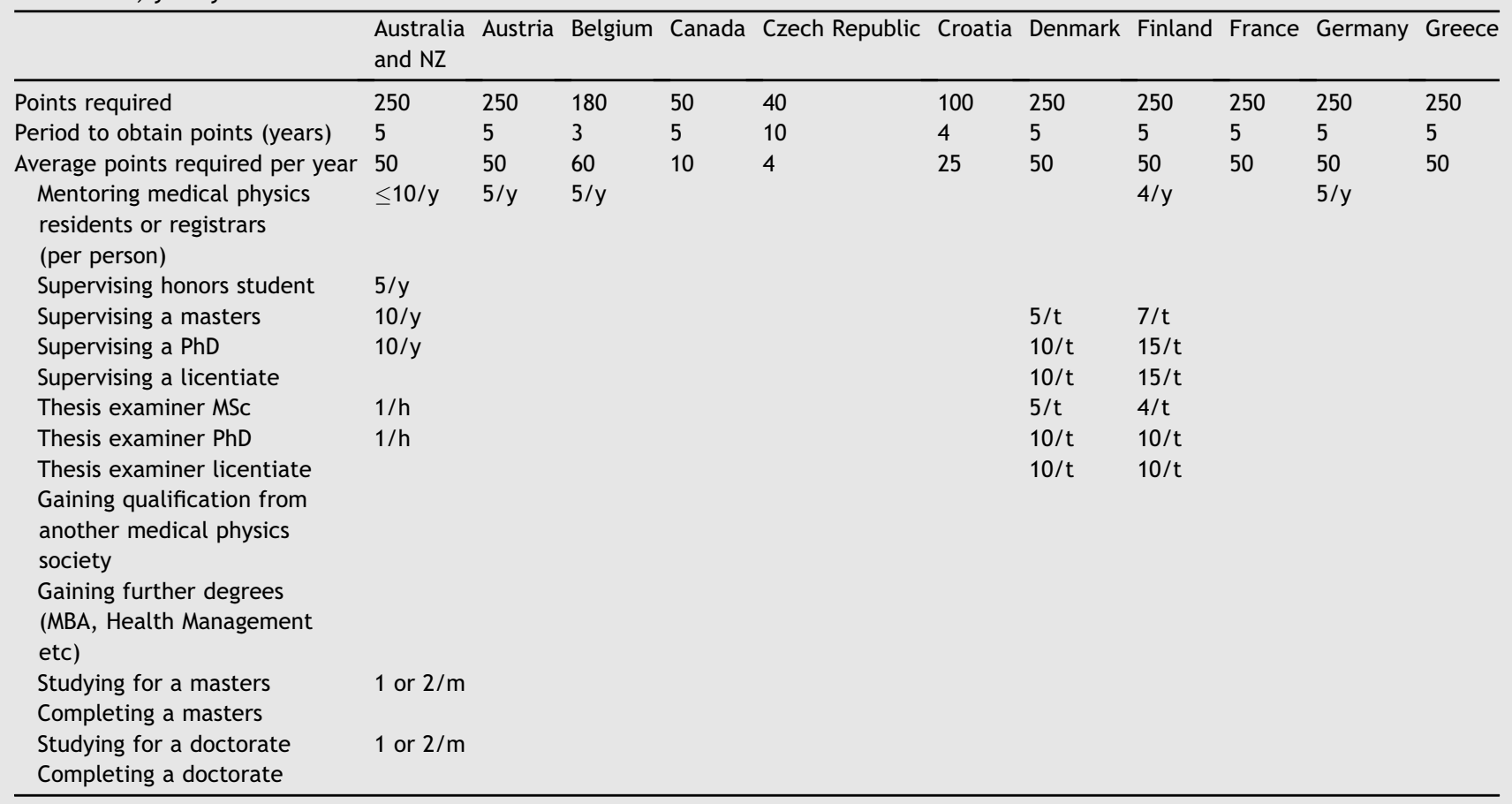




\begin{tabular}{|c|c|c|c|c|c|c|c|c|c|c|c|c|c|}
\hline Hong Kong & Ireland & Italy & Japan & Korea & Netherlands & Norway & Romania & South Africa & Spain & Sweden & Switzerland & Taiwan & $\begin{array}{l}\text { USA (ABR } \\
+ \text { CAMPEP) }\end{array}$ \\
\hline 90 & 250 & 150 & 60 & 30 & 200 & 250 & 250 & 60 & 250 & 250 & 250 & 500 & 250 \\
\hline 3 & 5 & 3 & 5 & 3 & 5 & 5 & 5 & 2 & 5 & 5 & 5 & 5 & 10 \\
\hline \multirow[t]{2}{*}{30} & 50 & 50 & 12 & 10 & 40 & 50 & 50 & 30 & 50 & 50 & 50 & 100 & 25 \\
\hline & $\leq 5$ & & & & & Varies & $\leq 5$ & & 5 & & & & \\
\hline \multirow[t]{3}{*}{3} & $\leq 5$ & & & & 5 & & $\leq 5$ & & 5 & & & & \\
\hline & & $1 / 2 \mathrm{~h}$ & & & & 1 or 2 & $5 / r$ & & & 1 or 2 & $2 / 1 / 2 d$ & & \\
\hline & & & & & & & & & $5 / y$ & & & & \\
\hline $3 / c$ & & & & & $5 / y$ & & & & $5 / y$ & & & & \\
\hline & & & & & & & & & 5 & & & & \\
\hline
\end{tabular}

approved by the body administering the CPD program before points can be awarded for that activity.

\section{Attending courses/seminars/lectures etc (Table 1)}

To obtain points for these activities there is commonly a requirement that the body administering the CPD system will approve the activity as having a set points value. The points value is typically equivalent to one point per hour of activity, although this can vary considerably, especially where the system requires only a small number of points to be obtained in a year. The point value of an activity is often increased if there is an examination after the activity to ensure that the participants have achieved an acceptable level of knowledge of the content. Point values may also depend on other factors such as whether the course, etc., is locally-based or whether it is an international event.

\begin{tabular}{|c|c|c|c|c|c|c|c|c|c|c|c|c|c|}
\hline Hong Kong & Ireland & Italy & Japan & Korea & Netherlands & Norway & Romania & South Africa & Spain & Sweden & Switzerland & Taiwan & $\begin{array}{l}\text { USA (ABR } \\
+ \text { CAMPEP) }\end{array}$ \\
\hline 90 & 250 & 150 & 60 & 30 & 200 & 250 & 250 & 60 & 250 & 250 & 250 & 500 & 250 \\
\hline 3 & 5 & 3 & 5 & 3 & 5 & 5 & 5 & 2 & 5 & 5 & 5 & 5 & 10 \\
\hline \multirow[t]{7}{*}{30} & 50 & 50 & 12 & 10 & 40 & 50 & 50 & 30 & 50 & 50 & 50 & 100 & 25 \\
\hline & & & & & $5 / y$ & & & $2 / y$ & & & $5 / y$ & & \\
\hline & & & & & & $0.25 / c$ & & & & & & & \\
\hline & & $4 / m$ & & & & $10 / y$ & & & & $10 / y$ & & & \\
\hline & & & & & $5 / y$ & & & & & & & & \\
\hline & 10 & & & & & 2 & & $5 / t$ & & $5 / t$ & & & \\
\hline & 15 & & & & 5 & 2 or 10 & & $5 / t$ & & $10 / t$ & & & \\
\hline \multicolumn{14}{|l|}{5} \\
\hline \multicolumn{14}{|l|}{$3-20$} \\
\hline \multirow[t]{2}{*}{$10 / y$} & & $50 / y$ & & & & & & $30 / y$ & & & & & \\
\hline & & & & & & & 3 & 30 & & & & 30 & \\
\hline \multirow[t]{2}{*}{$10 / y$} & & $50 / y$ & & & & & & $30 / y$ & $10 / y$ & & & & \\
\hline & & & & & 15 & & 5 & 30 & & & & 50 & \\
\hline
\end{tabular}




\section{Other learning (Table 1)}

There are learning opportunities for medical physicists other than attending lectures, courses and seminars and conferences. Self-directed learning in the form of reading journal papers is of value but this activity should be planned in conjunction with a controlling medical physicist rather than being done on an ad hoc basis. There are usually limits on how many points may be obtained through such activities in a single year. Interactive learning through the internet or using CD ROM based activities are becoming more common and often have a component of self-evaluation for the participants.

\section{Teaching (Table 2)}

Teaching is a valuable learning tool as it requires the teachers to update, evaluate, analyze and order what they intend to present to participants. Thus it is commonly accepted as a CPD activity. The basis on which points are awarded for such activities varies considerably and may not necessarily reflect the amount of time taken in the preparation of the teaching activity. However, it is common for a higher number of points to be awarded for delivering a new lecture compared to the number awarded for repeating an existing lecture.

\section{Research publication (Table 3 )}

The publication of research results is universally accepted as a CPD activity. Points are awarded according to the medium in which the research is presented (journal, conference, book, etc.) and according to the input of those involved (e.g., a higher number of points may be awarded to the first author). It may be argued that the number of points that are awarded is quite low in terms of the time taken to carry out and present or publish the research. As research is often a normal occupational activity for a clinical medical physicist, this is probably both sensible and acceptable.

\section{Editing and reviewing (Table 3 )}

This is not recognized by the majority of CPD systems. A case for it to be acceptable as a CPD activity can be made on the basis that it necessarily involves critical review of original research and comparison with other published research. It is therefore both educational and analytical.

\section{New technologies and procedures (Table 4)}

This is widely accepted as a CPD activity as it requires medical physicists to become familiar with new technologies and procedures and therefore is a learning exercise. There is usually a requirement that a formal report documenting technology/procedure must be produced before CPD points are awarded.

\section{Professional service (Table 4)}

Professional service is widely accepted as a valid CPD activity except for those systems that have a very strong education bias. As many forms of professional service require medical physicists to become familiar with a variety of new technical material and often require that material to be analyzed in some way, there is often a definite educational aspect to the service that should be recognized.

Academic and professional training supervision (Table 5) Almost half of the CPD systems recognize that participating in these activities has an educational aspect for the supervisor as well as for the students or residents being supervised. The supervisor necessarily has to be familiar with the research being carried out by the student and needs to stay up-to-date with the knowledge and skills that are required of a resident.

\section{Examination (Table 5)}

Examining theses is as valid as reviewing journal papers as a CPD activity because it involves critical review and analysis of new knowledge, although as with reviewing journal papers, this is not recognized as a CPD activity as commonly as research publication is.

\section{Obtaining higher qualifications (Table 5)}

This is recognized by a few countries with points being awarded on an annual basis and/or on the basis of completing a relevant qualification. A case may be made that in some cases, especially where the qualification is based on research, that the activity that has resulted in the award of a higher qualification will necessarily incur in the awarding of points under another category which would result in gaining extra points without extra effort.

\section{Employment}

A very small number of systems allow the awarding of points purely on the basis that the medical physicist is employed as a clinical physicist. This appears to be more of a case of ensuring that the medical physicist is actually practicing for the purposes of renewal of certification rather than to ensure that the medical physicist is up-to-date with modern practice. Therefore it can be argued that awarding points purely for being employed should not be part of a CPD system.

\section{Practice requirements}

Some countries have a requirement that a medical physicist must spend a certain minimum fraction of full-time employment in order to be able to continue to practice. In a few countries this is included in the CPD points system. It may be argued that this is inappropriate as CPD is supposed to educate and develop a medical physicist whereas it is possible for someone to continue in employment essentially repeating the same task and not developing professionally at all.

\section{MPPO-specific CPD activities}

Table 1 summarizes the activities that are commonly accepted by a number of countries as valid CPD activities. There are some activities that are seemingly unique to a single country or a few countries, or are specific requirements of individual countries. Some of these are:

Australia/New Zealand: Provisional patent acceptance, organizing conferences, chairing sessions, obtaining research grants gain points.

Canada: Supervisory responsibilities over other medical physicists gains points.

Czech Republic: Research itself gains points.

Finland: Medical physicists must do $60 \mathrm{~h} / 5$ years in radiation protection training. 
France: Points are awarded for the purchase of journals and books.

Italy: Points awarded for an activity may vary according the number of participants.

Romania: Points are deducted if medical physicists violate medical physics laws or cause radiation accidents or incidents by violating radiation protection rules.

South Africa: Medical physicists must obtain 5 points on ethics, human rights or medical law each year out of the 60 required over two years.

\section{Activities that are excluded as CPD by MPPOs}

There is a grey area between what should be included within a CPD program and that which shouldn't be included. Obviously routine, repetitive, day-to-day activities which do not require active and varied mental exertion and participation should not be included. But it is rare to find a defined CPD program that specifically lists activities that should not be included. For example, the Swedish CPD system lists examples such as lecturing if employed as an academic, routine in-service training, radiation protection education for personnel and mandatory education such as fire and rescue education. Netherlands excludes activities provided by companies for (potential) users of a product, visits to colleagues, and management. However, in other countries, some of these activities would be acceptable for CPD.

\section{Discussion}

\section{How much CPD should be required of medical physicists?}

In many countries participating in a formal CPD system and fulfilling its requirements is necessary to maintain one's license or certification. This may be a statutory requirement such as in South Africa where a medical physicist's legal right to practice may be withdrawn if the requirements are not met. In other countries, such as Australia, the MPPO may maintain its own voluntary register of qualified physicists that members may join if they are sufficiently experienced and qualified. Again, to remain on the register, they must maintain their CPD at a prescribed level. However, not being on the register may not legally preclude one from clinical practice but it may reduce one's employment opportunities.

The amount of CPD that should be required annually by a medical physicist is quite debatable and is somewhat problematic to define. This brings with it the implication that the CPD activity should be quantifiable and measured in some way to fulfill a legal, or MPPO-defined, requirement [41]. Quantification is satisfying to the physicist's ethos, and is done in all systems other than that of the United Kingdom.

The requirements of many CPD systems equate to the equivalent of between one and two weeks full-time equivalent activity per year. This level is quite sensible in that it ensures a sufficient level of education and development without significantly impinging on workplace commitments.
However, quantifying CPD activities in a way that ensures that a required level of participation is met is not a simple task. It can be quite challenging, especially as many medical physicists participate in informal CPD (such as reading journals) more than formal CPD such as attending courses [42]. Quantification is usually done using a system where points are awarded for participation in different activities and there is a requirement to achieve a certain number of points over a period of typically 3-6 years. Most systems operate on the basis that 50 points per year are required with one point being notionally equivalent to $1 \mathrm{~h}$ of activity. For many activities, such as attending conferences, equivalence is easy to justify, but in other cases such as writing journal papers or examining theses this is more difficult and the equivalence of one point to $1 \mathrm{~h}$ of activity does not readily apply. In such cases the hours involved results in a comparatively low number of points.

Suggestions have been made that CPD quantification systems have a failing in that they measure only CPD inputs, whereas what is of most importance is measuring how much the medical physicist has gained from CPD activities, i.e. outputs should really be measured [42]. This is far more difficult to do practically, although some CPD activities are followed by an examination or evaluation to provide an assessment of learning. But of greater importance is knowledge translation, i.e. ensuring that the new skills and knowledge are actually implemented by the medical physicist in everyday practice $[16,43]$. It must be recognized that CPD is a means to an end, and not an end in itself. CPD must not be done for the sake of just achieving points to fulfill a requirement. Its purpose is to professionally develop the medical physicist.

Equally, it must be recognized that the role of a medical physics teacher is not to teach students medical physics. The role of the teacher is to teach student to learn medical physics [44]. Bennett et al. [45] define six core competencies for continuing medical education educators for physicians that are equally applicable to CPD teachers for medical physicists. Medical physicists also have a responsibility to provide in-service training for clinical staff to reduce the risk of human error as well as keeping their own CPD up-to-date [46].

\section{Defining a CPD system's requirements}

The way a CPD system should be structured and what requirements should be placed on its participants should primarily be defined by the national MPPO as its members are the most qualified to be able to assess what should be required. This is the case for most CPD systems.

However, there are at least three CPD systems that are instituted by government rather than the national MPPO: South Africa, Italy and the Czech Republic. In all three cases the systems come under a blanket system of CPD that is applied to all health professions. This places limitations on the activities on the activities that can be included for CPD but can also include activities that would normally not be available to medical physicists. In the case of the Czech Republic the requirements are exceptionally low and can be achieved with only half a day of CPD activity per year. As such, the Czech system appears to be of negligible value in 
terms of ensuring that a medical physicist is up-to-date with current technology, techniques and practice.

Clearly, MPPOs that do not yet have a defined CPD system should develop one of their own before their countries governments impose one on them. Those that are imposed by governments are often designed to encompass many health professions. As such, they do not often properly meet the needs of medical physicists. However, where possible, an MPPO-initiated CPD system should be established with the agreement of the national health authorities [47].

\section{Balances in CPD systems}

Almost all documents that specify individual CPD systems begin with a statement of why it should be required of clinical medical physicists. While they all differ somewhat, they essentially are in agreement with those stated in EFOMP Policy Statement no. 10 [13] which gives the following reasons:

- to embrace the pace of change occurring in medical practice

- to promote excellence within the Profession

- to assist in the protection of the Public against incompetence

- CPD is a prerequisite of some statutory registration schemes

- it is a requirement of the Medical Exposure Directive.

While all of the above are important, the relative significance of each will vary from one individual medical physicist to another depending on many things such as their responsibilities and areas of practice.

There are at least two balances that must be achieved in any CPD system if it is to be successful and meet the needs of the participants: the quality-quantity balance and the career-stage balance.

Any system that relies on accumulating a required number of points over a certain period of years has an inherent risk that the participants will be more focused on gaining points rather than ensuring that they are developing as professionals. It is difficult to achieve this balance between "quality and quantity", but it can be done to an extent by limiting the number of points that can be gained for a certain activity or related group of activities over a specified period. This reduces the risk of a participant focusing on only one activity in which they can easily acquire points. CPD systems also rely on individuals to approach CPD with a level of integrity (often required by their MPPO's Code of Ethics) that will ensure that they will, in fact, try to improve professionally as their main objective.

The UK CPD systems is quite different from all others in that it does not specify a required amount of CPD activity to be undertaken, nor does it try to quantify CPD. Rather a record of CPD activity is kept by the individual which is countersigned by a superior, and a proportion of the records are audited each year. While this decreases the motivation to just gain points, the list of acceptable CPD activities is the broadest of any CPD system and contains activities that are expressly forbidden in other systems.

There is also a need to balance a CPD system's requirements to meet the needs of medical physicists as they progress in their careers, the focus of their work changes. In the very early stages it will consist mostly of training, clinical/service duties, and research. At the later stages, the focus is likely to change more towards responsibility for supervision, teaching and contributing to the profession. Also, some medical physicists will have a greater research focus, some will have a greater clinical focus and some may fulfill an almost entirely administrative function. Thus at different stages of one's career, the mix of CPD activities will change as the professional responsibilities of the individual changes. A CPD system must be able to accommodate all medical physicists at all stages of their careers. It must not force medical physicists to undertake CPD in areas that are of no relevance to what they do. At the same time it must encourage medical physicists to undertake a wide range of relevant activities, especially those that will extend and broaden their expertise.

\section{Remotely-located physicists}

In some countries, there is recognition that some medical physicists are sufficiently remotely-located from their colleagues that it can be difficult for them to attend some CPD activities that others in large centers find it easy to access. For example, the Australia and New Zealand system is designed so that remotely-located medical physicists can achieve all credits required through structured self-study, teleconference meetings and publishing. Also, in Taiwan, medical physicists located in remote regions are awarded points at 1.2 times the normal rate for each activity.

While in many countries there may not be any remotelylocated medical physicists, in those where this may make access to CPD activities difficult sensible measures must be built into the CPD system.

\section{Administering and auditing CPD systems}

There must be an auditing process to ensure that the CPD requirements are being met. This may be done by a central government authority or by an MPPO either acting under its own authority or under authority granted by government. The usual requirement is for an individual to keep a record of their CPD activities (either on paper, or on an on-line system implemented by an MPPO). At regular intervals this has to be checked to ensure that the record is valid (i.e. audited) and that sufficient activities have been undertaken. The auditing may be done on all individuals, or a random sample of individuals may be audited. Often individuals must keep evidence of what they have done and this may need to be countersigned by a superior to ensure that the system is robust.

\section{Overcoming non-compliance}

It is inevitable that some medical physicists will not meet their CPD requirements and need to be encouraged to get procure more points within an short period or undergo further training or supervision, after becoming noncompliant. This is very important where there is a legal requirement for CPD to be up-to-date. Surprisingly few 
systems seem to specifically state what action must be taken in these circumstances. Some that do are:

Canada: Medical physicists can become re-certified through the normal examination process or through an oral exam.

Hong Kong: Participants are given 6 months to make up deficit.

South Africa: Participants are given 6-12 months to get their CPD up-to-date. If they do not comply, then they may be de-registered and be required to be supervised or to take a specified remedial program or an examination.

\section{What resources are required?}

CPD requires resources in the form of finance, time, and education/training expertise. This should be provided by the individual, the MPPO, the employer and public education/training bodies [1]. The provision of resources can be difficult for MPPOs in developing countries and especially in developed countries where the number of medical physicists is small.

The major resources required for a CPD system are

- People to decide on points values for activities, administer systems and audit records. These people may be volunteers from MPPOs or may be employees of either government or of the MPPO. The workload may be considerable for a CPD system with many participants.

- On-line services to provide resources and to log and monitor the activities that individuals undertake and complete. Some systems just rely on an individual keeping a paper record, but a backed-up on-line system is preferable and reduces the possibility of records being lost.

- CPD teaching resources. Many CPD activities, such as conferences and publication, do not have resource implications for a CPD system. Access to educational material in the form of on-line symposia, webinars, etc., are of value but are costly to produce.

It is important that resources are properly funded, but it is also important that CPD must be cost effective to avoid waste of resources [1]. Evaluation systems are needed to ensure the best resource allocation, although evaluation (e.g. [48]) is not often done.

The medical physics community must recognize that there is a need for international cooperation in the preparation and sharing of these materials. Resources are costly to develop and make available in terms of time and expense, and duplicated effort should be avoided. Such coordination would be a major challenge for MPPOs, but it would benefit all in the profession.

\section{Concluding remarks}

CPD systems for clinical medical physicists are quite common and more MPPOs are introducing them either voluntarily or in response to statutory requirements. Quantifying CPD in a systematic and fair way that practicing physicists can reasonably comply with is challenging. Various balances have to be met and the administration of the systems must not be such that it becomes a burden to the MPPOs or the participants. CPD can take many forms and activities by one country may not always meet the approval of all countries. Different cultures in different countries mean that there will not always be universal agreement. But it must be remembered that CPD is to fulfill purposes that can be met in many ways. A system defined by an MPPO is only a means to an end, not an end in itself.

\section{Acknowledgments}

Many colleagues provided information and contributed to the collection and validation of the data presented in this paper. The author wishes to acknowledge the input of:

Elizabeth Makonis (Australia), Werner Schmidt (Austria), Georg Stuecklschweiger (Austria), Michel Odile (Belgium), David Wilkins (Canada), Nenad Kovačević (Croatia), Jaroslav Ptáček (Czech Republic), Søren Hansen (Denmark), Søren Holm (Denmark), Stephanie Corde (Australia, France), Toni Ihalainen (Finland), Dominique Ledu (France), Laura Schreiber (Germany), Irmgard Griessbach (Germany), Antonis Stefanoyiannis (Greece), Kin Yin Cheung (Hong Kong), Pedroli Guido (Italy), Luisa Begnozzi (Italy) Fintan Bradley (Ireland), Wil van der Putten (Ireland), Shigekazu Fukuda (Japan), Youngyih Han (South Korea), Esther Raaijmakers (Netherlands), Sigrun Almberg (Norway), Rune Hafslund (Norway), Marin Bodale (Romania), Ti-Chuang Chiang (Taiwan), María Jose Rot San Juan (Spain), Hans-Erik Kallman (Sweden), Fred Corminboeuf (Switzerland), Stephan Kloeck (Switzerland), Raphael Moeckli (Switzerland), Hans W. Roser (Switzerland), Daniel Vetterli (Switzerland), Virginia Mosiamo (South Africa), William Rae (South Africa).

\section{References}

[1] Brown CA, Belfield CR, Field SJ. Cost effectiveness of continuing professional development in health care: a critical review of the evidence. Brit Med J 2002;323:652-5.

[2] Round WH. Continuing professional development programs for medical physicists. Jap J Med Phys 2011;31(Supplement Suppl. 4):80.

[3] Christofides S, Schlegel W, Padovani R, Sharp PF, Torresin A, Wasilewska-Radwanska $M$, et al. Education and training of the medical physicists in Europe. In: Dossel O, Schlegel WC, editors. IFMBE proceedings 25/XIII. Springer; 2009. p. 1-4.

[4] Eudaldo E, Olsen K. The present status of medical physics education and training in Europe; an EFOMP survey. Phys Med 2008;24:3-30.

[5] Stefanoyiannis AP, Georgiannis I, Psichis C, GeronikolaTrapali N, Armeniakos I, Prentakis A, et al. Education and training of physicists in Europe. J Eng Sci Technol Rev 2008;1: 62-5.

[6] Canadian College of Physicists in Medicine. Policy and procedure manual. In URL: http://www.ccpm.ca/media.php? mid $=1955$.

[7] American Board of Radiology http://www.theabr.org/moc/ moc_rp_landing.html.

[8] Commission on Accreditation of Medical Physics Educational Programs. CAMPEP online. In URL: http://www.campep.org/ mainlaunchsite.asp.

[9] Round WH, Fukuda S, Han Y, Chiang TC, Cheung KY. Continuing professional development systems in AFOMP countries. Jap J Med Phys 2011;31(Supplement Suppl. 4):81. 
[10] Health Professions Council of South Africa. Continuing professional development guidelines for the health care professionals. In URL: http://www.hpcsa.co.za/downloads/ cpd/activities_2011/guidelines_2011.pdf.

[11] Institute of Physics and Engineering in Medicine. Continuing professional development. In URL: http://www.ipem.ac.uk/ SiteCollectionDocuments/CPD/Guidance\%20Notes.pdf.

[12] Eudaldo T, Huizenga H, Lamm IL, McKenzie A, Milano F, Schlegel W, et al. Guidelines for education and training of medical physicists in radiotherapy recommendations from an ESTRO/EFOMP working group. Rad Oncol 2004;70:125-35.

[13] EFOMP Policy Statement No 10: Recommended guidelines on national schemes for continuing professional development of medical physicists. Phys Med 2001; XVII: 97-101.

[14] Dendy PP. Education and training: medical physicists and engineers. Rad Prot Dosimet 2000;90(1-2):57-61.

[15] Friedman A, Phillips M. Continuing professional development: developing a vision. J Work Educ 2004;17:361-76.

[16] Davis D, Evans M, Jada A, Perrier L, Rath D, Ryan D, et al. The case for knowledge translation: shortening the journey from evidence to effect. Brit Med J 2003;327:33-5.

[17] Bierema LL, Eraut M. Workplace-focused learning: perspective on continuing professional education and human resource development. Adv Devel Hum Res 2004;6(1):52-68.

[18] Nordic Association for Clinical Physics. NACP recommendations on CPD. In URL: http: / /www.nacp-nordisk.org/files/pdf/Final_ report_to_NACP_council_by_CPD_working_group.pdf.

[19] Australasian College of Physical Scientists and Engineers in Medicine. Education within the ACPSEM. In URL: http://www. acpsem.org.au/index.php/education.

[20] Austrian Society for Medical Physics. Point system for evaluating training activities (in German). In URL: http://www. oegmp.at $/$ index.php?option $=$ com_docmanandtask $=$ doc downloadandgid $=31$ andltemid $=105$.

[21] Belgium Hospital Physicists Association. http://www.bhpa.eu/.

[22] Croatian Medical and Biological Engineering Society. http:// www.crombes.hr/.

[23] Czech Society of Physicists in Medicine. Lifelong learning (in Czech). In URL: http://www.csfm.cz/celozivotni-vzdelavani. html.

[24] Danish Society for Medical Physics. CPD system (in Danish). In URL: http://www.dsmf.org/dsmf/cpd-systemet/.

[25] Finnish Association of Hospital Physicists. CPD (in Finnish). In URL: http://www.sairaalafyysikot.fi/cpd/cpd.html.

[26] French Society of Medical Physics. Renewal of registration on the professional register of SFPM (in French). In URL: http://www. sfpm.fr/download/fichiers/docs_sfpm/cr-renouvellement_ inscription.pdf.

[27] German Society for Medical Physics. Further education regulations of the German Society for Medical Physics (in German). In URL: http://www.dgmp.de/fachanerkennungskommission/ wfbo/WBO2010.pdf.

[28] Hellenic Association of Medical Physicists: http://www.efie. $\mathrm{gr} / \mathrm{cms} /$.

[29] Hong Kong Association of Medical Physics http://www.hkamp. org/hkamp/index.html.

[30] Italian Ministry of Health. Continuing education in medicine (in Italian). In URL: http://www.salute.gov.it/ecm/ecm.jsp.
[31] Irish College of Medical Physicists www.irishcollegeofmedical physicists.roundtablelive.org/.

[32] Japanese Board for Medical Physicist Qualification. Updated points system for medical physicists (in Japanese). In URL: http://www.jbmp.org/contents/regulations/tanni_table.pdf.

[33] Korean Society of Medical Physics. http: //www.ksmp.or.kr.

[34] Dutch Society for Medical Physics. Medical physicists' reregistration system (in Dutch). In URL: http://www.nvkf.nl/ images/Bestanden/Kenniscentrum/Herregistratie/NVKF_ Herregistratiesysteem.pdf.

[35] Norwegian Society for Medical Physics. Continuing Professional Development of Medical physicist specialists (in Norwegian). In URL: http://www.nfmf.org/index.php?/nor/ Sertifisering/CPD.

[36] National Commission for Nuclear Activities Control. Rules concerning the expert in medical physics (in Romanian). In URL: http://www.cncan.ro/assets/NSR/nsr38-norme-expertfiz-med.pdf.

[37] Spanish Society for Medical Physics. Continuing Education for Practitioners (in Spanish). In URL: http://www.sefm.es/fisicamedica/es/formacion/5/programa-profesional-fcp/39.

[38] Swedish Association of Medical Physics. Swedish CPD Program. In URL: http://www.sjukhusfysiker.se/cpd/SwedishCPDProgram. html.

[39] Swiss Professional Association of Medical Physicists. Requirements for being a medical physics specialist of the Swiss Professional Association of Medical Physicists (in French). In URL: http://www.medphys.ch/documents/apspm_specialisation_ ssrpm_annexes.pdf.

[40] Chinese Society of Medical Physics, Taipei. CPD requirements (in Chinese). In URL: http://www.csmpt.org.tw/xms/ content/show.php?id $=381$.

[41] EFOMP Policy Nr. 8: Continuing Professional Development for the Medical Physicist. Phys Med 1998; XIV (2):81-83.

[42] Watkins J. UK professional associations and continuing professional development: a new direction? Int J Life Educ 1999;18(1):61-75.

[43] Graham ID, Logan J, Harrison MB, Straus SE, Tetroe J, Caswell W, et al. Lost in knowledge translation: time for a map? J Cont Ed Health Prof 2006;26(1):3-24.

[44] Starkschall G. Editorial: medical physicists as educators. J Appl Clin Med Phys 2009;10:3 [Online] Available from: http:// www.jacmp.org/index.php/jacmp/article/view/3147/1659.

[45] Bennett NL, Davis DA, Easterling WE, Friedmann P, Green JS, Koeppen BM, et al. Continuing medical education: a new vision of the professional development of physicians. Acad Med 2000;75(12):1167-72.

[46] Halvorsen PH, Dawson JF, Ibbott GS, Thomadsen BR. AAPM Report no 80: the solo practice of medical physics in radiation oncology. Madison, USA: Medical Physics Publishing; 2003.

[47] EFOMP Policy No 9: Radiation protection of the patient in Europe: the training of the medical physics expert in radiation physics or radiation technology. Phys Med 1999; XV: p. 149-153.

[48] Perkins A, Kron T. Continuing professional development needs of Australian radiation oncology medical physicists - an analysis of applications for CPD funding. Austral Phys Eng Sci Med 2007;30(3):226-32. 